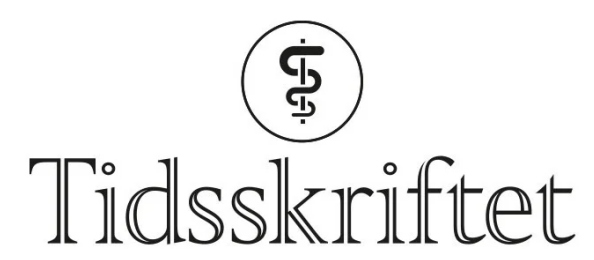

DEN NORSKE LEGEFORENING

\title{
Tankevekkende om psykisk helsearbeid
}

ANMELDELSER

\section{SVEIN FRIIS}

Overlege, Klinikk psykisk helse og avhengighet Oslo universitetssykehus

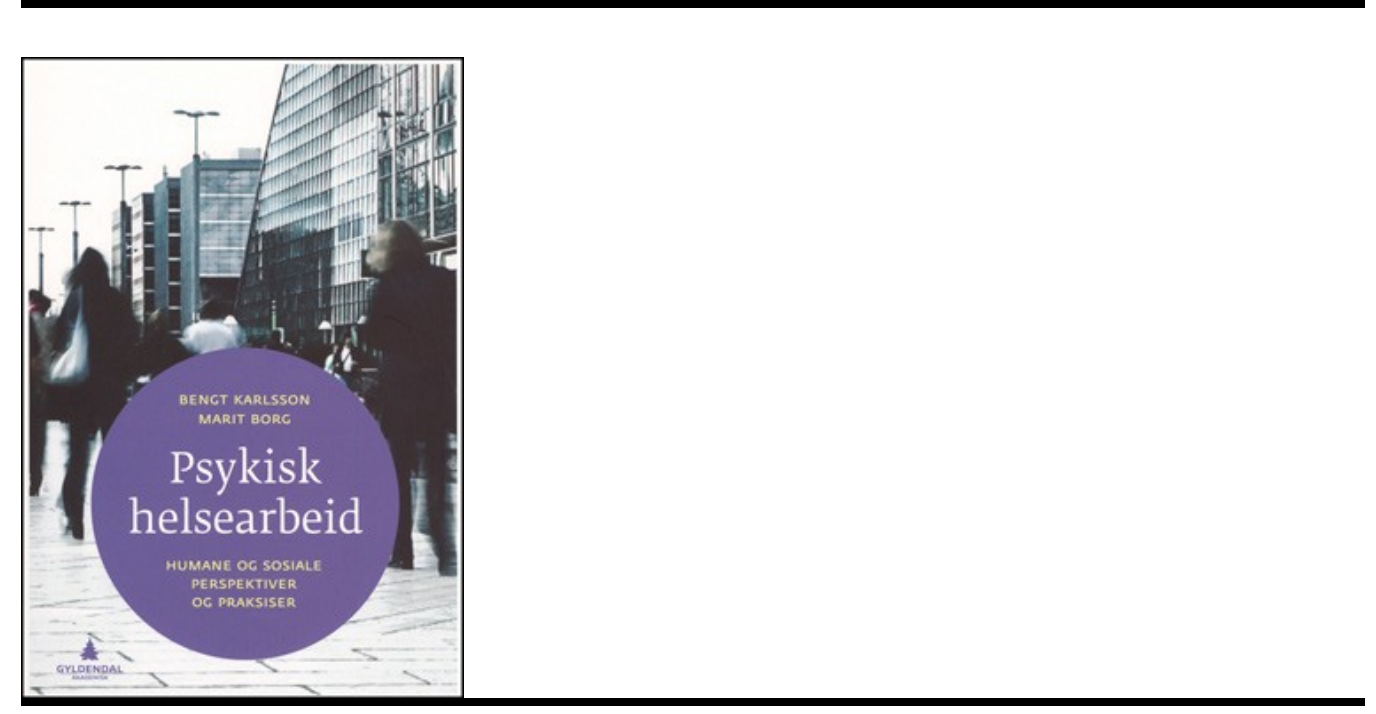

Karlsson, Bengt

Borg, Marit

Psykisk helsearbeid

Humane og sosiale perspektiver og praksiser. 213 s. Oslo: Gyldendal Akademisk, 2013. Pris NOK 345

ISBN 978-82-05-42015-1

Forfatternes formål er «å løfte frem det humane og det sosiale perspektivet i arbeidet med psykisk helse». Jeg forstår dem slik at de først og fremst henvender seg til fagpersoner innen psykisk helsearbeid og til brukere av tjenestene. 
De tre delene, Humane og sosiale grunnlagsforståelser, Det sosiale perspektivet og Kontekster og praksiser, er tankevekkende på flere plan. Først og fremst fordi de inneholder mye klokt og viktig. Forfatterne understreker behovet for det relasjonelle perspektivet og at brukere og pårørende møtes med respekt og inviteres til aktiv medvirkning. De legger vekt på sosiale og samfunnsmessige forståelser og forklaringer, på dialog med brukerne og på at personer med psykisk uhelse er eksperter på egne liv og kan ta ansvar for å mestre dem.

Det er et klart og tydelig budskap om å erstatte monolog og ekspertvelde med dialog og jevnbyrdighet. Samtidig har boken en polemiserende stil som står i tankevekkende kontrast til budskapet om dialog. Forfatterne må ha vært oppmerksomme på denne kontrasten, for de skriver i innledningen: «Văr ambisjon er å løfte frem og tidvis insistere på vår forståelse - ikke fordi det er det eneste sanne og rette, men for å understreke nødvendigheten av det humane og sosiale perspektivet. Dette innebærer at teksten tidvis kan være lite dialogisk, i den forstand at den blir mer argumenterende i sitt perspektiv enn drøftende og overveiende. Det kan fremstå som en utfordring ved boken, særlig gitt dens dialogiske grunntone.»

Etter min mening er grunntonen mer polemisk enn dialogisk. Forfatterne skriver for eksempel: «Den hjelpen som er blitt gitt i psykisk helsevern har i for lang tid vært utviklet på hjelperens eller ekspertens premisser. Dette har ført til inhumane praksiser som sosial ekskludering, stigmatisering, overgrep og undertrykkelse.» Dette blir for meg en svært enkel problemforståelse. Psykisk helsevern har hatt gjentatte forsøk på reformer i retning av mer dialog og mindre ekspertvelde. Et eksempel er det terapeutiske samfunn med slagordet "Culture of inquiry», undringskulturen. Jeg deler forfatternes bekymring for at vi i dag ser altfor lite til en slik kultur, og at krav til produksjon, pasientgjennomstrømming og tidseffektivitet truer betingelsene for samtalen i terapeutisk arbeid.

Forfatterne tar opp mange viktige spørsmål som burde gi grunnlag for en bred dialog som inkluderer alle aktører i psykisk helsearbeid. Men det vil kreve et genuint ønske om dialog på bred front.

Publisert: 25. mars 2014. Tidsskr Nor Legeforen. DOI: 10.4045/tidsskr.13.166o

(C) Tidsskrift for Den norske legeforening 2023. Lastet ned fra tidsskriftet.no 26. april 2023. 